\title{
Detection of carp antibodies to spring viraemia of carp virus by a competitive immunoassay
}

\author{
P. F. Dixon ${ }^{1}$, A.-M. Hattenberger-Baudouy ${ }^{2}$, K. Way ${ }^{1}$ \\ ${ }^{1}$ Ministry of Agriculture, Fisheries and Food, Directorate of Fisheries Research, Fish Diseases Laboratory, Weymouth, \\ Dorset DT4 9TH, United Kingdom
}

${ }^{2}$ CNEVA, Laboratoire Central de Recherches Veterinaires, 22 rue Pierre Curie, BP 67, F-94703 Maisons-Alforts Cedex, France

\begin{abstract}
A competitive immunoassay for the detection of spring viraemia of carp virus (SVCV) antibodies in fish was developed in order to screen fish stocks for previous exposure to the virus. SVCV has been isolated from different fish species and the use of a competitive immunoassay overcomes the requirement of standard immunoassays for antisera prepared against the immunoglobulin of each species under test; instead, the test fish serum competes with an antiserum against SVCV for binding sites on the virus. The competitive assay was developed and tested using sera from common carp containing antibodies that had been induced either experimentally, or as a result of field exposure to the virus. When immunoassay results were compared with results of virus neutralisation tests on the sera from 2 groups of experimentally challenged fish, there was no correlation between the 2 techniques. Similar results were obtained with 4 groups of field-collected sera. One group had $34.6 \%$ neutralisation-positive sera, but $88.5 \%$ immunoassay-positive sera. The 3 remaining groups were negative by virus neutralisation, but each group had a small number $(11.4,8.3$ and $11.5 \%$ respectively) of immunoassay-positive sera. The competitive immunoassay thus appears to be more sensitive than the neutralisation test. The assay has potential for use in large-scale screening of fish populations but further validation on a wider range of sera is needed.
\end{abstract}

KEY WORDS: Spring viraemia of carp virus · Antibody detection · Competitive immunoassay

\section{INTRODUCTION}

In recent years there has been a growing interest in the health screening of fish by means of detecting specific antibodies against fish pathogens (Dixon 1989, Groot \& Dixon 1989, Hattenberger-Baudouy et al. 1989b, Jørgensen et al. 1991, Olesen et al. 1991). This is partly because of national and international legislation or policy on fish health monitoring. In addition, the wider use of immunoassay techniques employing 96-well microplates makes large-scale screening for antibodies feasible and, particularly in the case of viruses, more economical than standard pathogenisolation methods. With certain fish virus diseases, notably those caused by rhabdoviruses, it is not possible to isolate virus from carrier fish at all times of the year. For instance, infectious haematopoietic necrosis virus (IHNV) can usually only be isolated from clinically diseased fry or from adults at spawning time (Mulcahy et al. 1984); viral haemorrhagic septicaemia virus (VHSV) can only be isolated from infected fish for a short period after the onset of clinical symptoms at high water temperatures (e.g. $20^{\circ} \mathrm{C}$ ), whereas at low water temperatures (e.g. $5^{\circ} \mathrm{C}$ ), the virus can be isolated for a much greater period (Jørgensen 1992); and spring viraemia of carp virus (SVCV) can usually only be detected during outbreaks of clinical disease (Dresenkamp 1986) which predominantly occur at water temperatures between 11 and $17^{\circ} \mathrm{C}$ (Fijan 1988). However, it has been demonstrated that fish populations previously exposed to a virus could be identified by an antibody detection method when they were negative by virus isolation (Hattenberger-Baudouy et al. 1989b). As blood samples can be taken without killing fish, the use of antibody detection methods avoids the unnecessary sacrificing of older, more valuable fish for sampling purposes.

SVC is regarded as exotic to Great Britain, although the virus was isolated there in 1977 (Bucke \& Finlay 1979), and the disease has occurred since in isolated 
holding facilities, usually being associated with imported fish. In each case the holding facilities were successfully disinfected with no further recurrence of infection. However, in spring/early summer of 1988 , SVCV was detected in 35 different sites in England and Wales; the outbreak is believed to have been as a result of importation and subsequent transfer of infected fish (Anonymous 1989). Fish at 176 sites receiving fish from any of those initial infected sites had to be examined virologically to determine whether SVCV had been transferred. Because of the large number of virus tests required, it was decided to develop an immunoassay to screen suspected fish for specific antibodies against the virus should such a large-scale outbreak recur.

Immunoassays have provicusly bocn doveloped to detect antibodies against SVCV (Rodák et al. 1986, Kretzschmar \& Dresenkamp 1987), but those assays were specific for detecting antibodies in carp and employed rabbit antisera produced against carp immunoglobulin. Besides the common carp Cyprinus carpio, SVCV has been isolated from crucian carp Carassius carassius (Kölbl 1975), silver carp Hypophthalmichthys molitrix (Roudikov 1980), sheatfish Silurus glanis (Fijan et al. 1981), bighead carp Aristichthys nobilis and grass carp Ctenopharyngodon idella (Shchelkunov \& Shchelkunova 1989), tench Tinca tinca, and orfe Leuciscus idus (P. Dixon, E. Hudson, D. MCGregor, C. Rodgers \& K. Way unpubl. data). To avoid having to prepare antisera against the immunoglobulins from all naturally and experimentally susceptible species, it was felt to be more appropriate to develop a competitive (inhibition) immunoassay, such as that used to detect fish antibodies against pathogenic bacteria (Chart et al. 1984). In a competitive assay, any specific antibodies in a test serum compete with a standard serum for binding sites on the specific antigen; the lowered binding of the standard serum can be determined and used as a measure of the competing, test antibodies. The method does not require antisera against immunoglobulins from each fish species, only a standard antiserum produced against SVCV. This report details the development of such an assay.

\section{MATERIALS AND METHODS}

Virus. SVCV for competitive assay development was obtained from Dr N. Fijan, Zagreb, former Yugoslavia, and that used in virus neutralisation was obtained from Dr N. Fijan via Dr C. Pfeil-Putzien, Munich, Germany. Virus was grown in fathead minnow (FHM) cells (Gravell \& Malsberger 1965) or Epithelioma papulosum cyprini (EPC) cells (Fijan et al. 1983) as described previously (Baudouy et al. 1980, Way 1991).
Carp serum. Carp were bled from the caudal vein into a disposable container, and the blood was allowed to clot. The serum was clarified by centrifugation at $1000 \times g$ for $10 \mathrm{~min}$ and tested immediately or stored at $-20^{\circ} \mathrm{C}$. The fish were from fisheries/farms in areas of France where SVC was known to be endemic, those areas having been regularly tested since its first identification there (Baudouy 1975), and from fisheries/farms in England where there was no evidence of SVC having been present. The carp weighed from $300 \mathrm{~g}$ to $3 \mathrm{~kg}$, and sera were collected in February, March, April and November. Sera were also collected from $2.5 \mathrm{yr}$ old fish that had been challenged with SVCV by the method described by Baudouy et al. (1980), after vaccination when $1.5 \mathrm{yr}$ old by intraperitoneal injection of $\beta$-propiolactoneinactivated SVCV (P. de Kinkelin \& A.-M. Hattenberger-Baudouy unpubl, data).

Virus neutralisation. The micro-technique based on that employed by Kinkelin et al. (1985) and Hattenberger-Baudouy et al. (1989a) was used. Briefly, carp serum was inactivated for $30 \mathrm{~min}$ at $45^{\circ} \mathrm{C}$ and $50 \mu \mathrm{l}$ of 2-fold dilutions in Stoker's medium (Stoker \& MicPherson 1961) supplemented with 10\% tryptose phosphate (maintenance medium, MM) starting at 1:8 were distributed in 96-well microtitre plates (Greiner). Volumes of $50 \mu \mathrm{l}$ of $\mathrm{MM}$ containing 100 $\mathrm{TCID}_{50}$ of SVCV were added, mixed, and incubated for $1 \mathrm{~h}$ at $20^{\circ} \mathrm{C}$. Each plate contained positive and negative controls. To each well, $50 \mu \mathrm{l}$ of Stoker's medium (supplemented with 10\% tryptose phosphate and $10 \%$ foetal calf serum) containing $1.75 \times 10^{5} \mathrm{EPC}$ cells were then added and the plates were incubated at $15^{\circ} \mathrm{C}$ until complete cytopathic effect (CPE) was observed in negative controls. The cells were fixed with $10 \%$ neutral buffered formalin, stained with $1 \%$ crystal violet, and the neutralisation titre determined.

Competitive immunoassay. The competitive immunoassay was based on the noncompetitive immunoassay for SVCV antigen described by Way (1991). The production of a rabbit antiserum against SVCV, $\gamma$-globulin purification and conjugation of alkaline phosphatase, EC 3.1.3.1 to the $\gamma$-globulin were as described by Way (1991). Microtitre plates (Costar) were coated with $5 \mu \mathrm{g} \mathrm{ml^{-1 }} \gamma$-globulin, $100 \mu \mathrm{lwell}^{-1}$ overnight at $25^{\circ} \mathrm{C}$. After a wash in phosphate buffered saline (PBS) containing sodium azide (PBSN), the wells were blocked with $1.5 \%$ bovine serum albumin (BSA), $200 \mu \mathrm{l}$ well ${ }^{-1}$, for $1 \mathrm{~h}$ at $37^{\circ} \mathrm{C}$. Plates were washed in PBS containing $0.05 \%$ Tween 20 (PBST) and then $100 \mu$ well $^{-1}$ of a 1:20 dilution of the capture antigen was added to alternate rows of the plate. The capture antigen was prepared from SVCV-infected FHM cell cultures showing complete CPE which had been soni- 
cated $(20 \mathrm{kHz}, 6 \mu \mathrm{m}$ peak to peak) in six $10 \mathrm{~s}$ bursts, then clarified at $1500 \times g$ for $30 \mathrm{~min}$ at $4{ }^{\circ} \mathrm{C}_{i} 100 \mu \mathrm{l}$ well $^{-1}$ of the same dilution of a control FHM cell culture treated in the same manner was added to the remaining rows. The control cell cultures acted as a control for nonspecific binding of each test serum. Infected and noninfected cell cultures were diluted in PBST containing $1 \%$ Nonidet P40 (Sigma Chemical Co.). Following incubation for $1 \mathrm{~h}$ at $37^{\circ} \mathrm{C}$, the plates were washed in PBST after which carp sera diluted 1:10 in PBST containing $1 \%$ BSA (PBST-BSA) were added in duplicate $\left(100 \mu \mathrm{l}_{\text {well }}^{-1}\right)$ to wells previously incubated with the virus-infected cell harvest, and to wells previously incubated with the control cell harvest. After further incubation of $1 \mathrm{~h}$ at $25^{\circ} \mathrm{C}$, followed by a wash with PBST, $\gamma$-globulin (from a rabbit antiserum prepared against SVCV) conjugated with alkaline phosphatase (hereafter referred to as conjugate) diluted 1:300 in PBST-BSA was added $\left(100 \mu \mathrm{l}_{\text {well }}{ }^{-1}\right)$ and incubated for $1 \mathrm{~h}$ at $25^{\circ} \mathrm{C}$. The plates were again washed in PBST and then incubated with $\mathrm{p}$-nitrophenol phosphate substrate, $200 \mu \mathrm{l} \mathrm{well}-1$, for $20 \mathrm{~min}$ at $37^{\circ} \mathrm{C}$. The reaction was stopped by the addition of $50 \mu \mathrm{l}$ well ${ }^{-1}$ of $3 \mathrm{M}$ sodium hydroxide and the absorbance of the hydrolysis product read at $405 \mathrm{~nm}\left(A_{405}\right)$ on a microplate reader (MR 7000, Dynatech). Each plate contained positive and negative controls. The maximum colour development in each test was determined from wells into which PBST-BSA was pipetted instead of carp serum. The results were expressed as \% inhibition of the maximum $A_{405}$

The conditions for the competitive immunoassay were initially determined using $\gamma$-globulin from a rabbit antiserum against SVCV competing against conjugate. Checkerboard titrations were set up using virus-infected cell harvest diluted 1:2, 1:20 and 1:200, $\gamma$-globulin at 10,1 and $0.1 \mu \mathrm{g} \mathrm{ml} \mathrm{m}^{-1}$, and conjugate diluted 1:300, 1:600 and 1:900.

Once suitable reagent dilutions had been found, an experiment was conducted to determine whether it would be better to add the carp sera and conjugate sequentially, or to add them simultaneously (which would reduce the time for the assayj. An immunoassay antibody-positive carp serum was diluted in 2 series: the first series was 1:10, 1:20,1:80, 1:320 and $1: 1280$, and the second series was $1: 5,1: 10,1: 40$, $1: 160$ and $1: 640$. The first series was added to the microtitre plate, followed after a wash with PBST by conjugate diluted to 1:300. The second series was mixed with an equal volume of conjugate diluted $1: 150$ (producing a conjugate dilution of $1: 300$ and carp serum dilutions equivalent to those in the first series) and the mixture added to the wells of a microtitre plate. All other stages of the assay were identical.
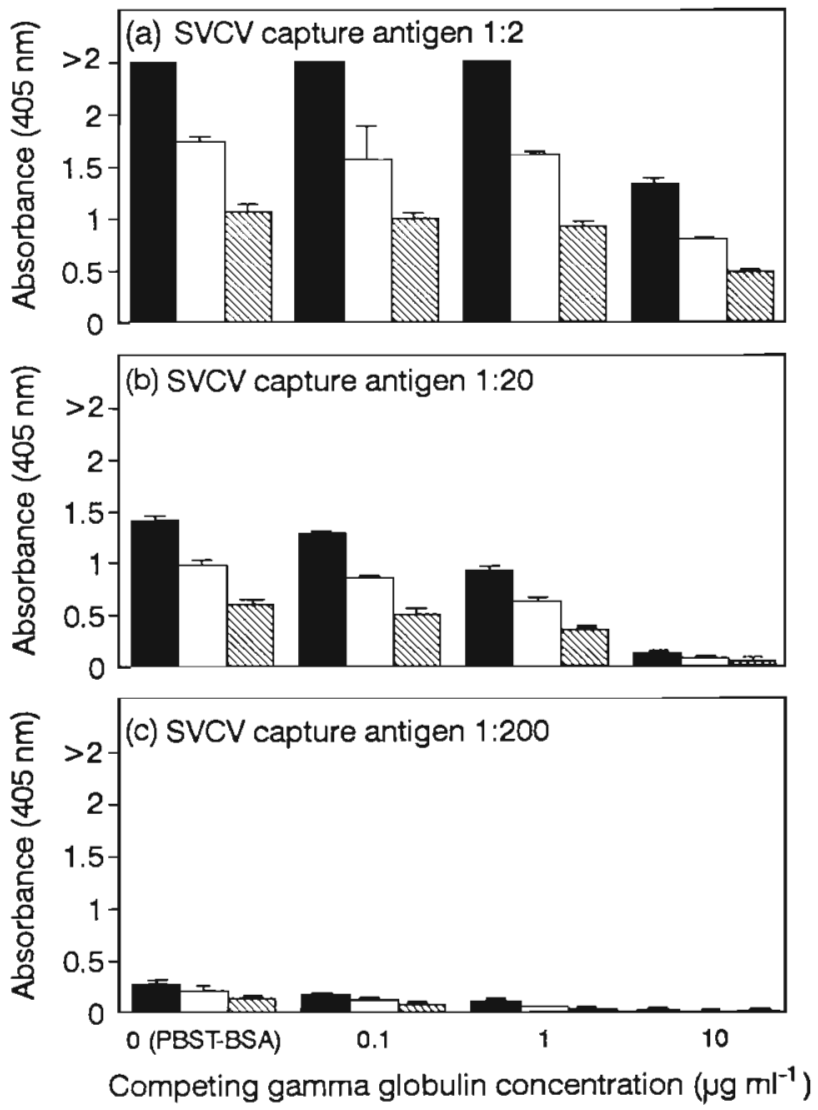

Fig. 1. Checkerboard titrations of conjugate, competing $\gamma$-globulin and capture antigen. SVCV antigen (capture antigen) derived from an infected cell harvest was diluted (a) 1:2, (b) 1:20 and (c) 1:200 and indirectly attached to wells of microtitre plates. Rabbit $\gamma$-globulin (at $0.1,1.0$ and $10 \mu \mathrm{g}$ $\mathrm{ml}^{-1}$ ) from an antiserum against SVCV competed with conjugate (prepared from the same antiserum), diluted 1:300 (ש), 1:600 ( $\square$ ) and 1:900 (\$), for attachment to the capture antigen. The negative control for competition was produced by substituting PBST-BSA in place of competing $\gamma$-globulin. Mean (+SD) absorbance values are shown

\section{RESULTS}

\section{Competitive assay development}

The results of the checkerboard titrations to determine suitable dilutions of reagents are shown in Fig. 1. For each conjugate dilution at a given capture antigen concentration, the maximum absorbance value was seen where there was no competing $\gamma$-globulin (a control in which the competing $\gamma$-globulin was replaced by PBST-BSA); as the competing $\gamma$-globulin concentration increased, less conjugate attached to the capture antigen and so there was a reduction in the absorbance value. From those titrations, the conditions chosen for subsequent assays were: antigen, 1:20 dilution of infected or control cell harvest; conjugate, 
1:300 dilution. A carp serum with a neutralising antibody titre of $1: 128$, and a neutralising antibodynegative serum from carp in an SVC-free area were tested using the above conditions. Those sera inhibited the standard colour development by 71.3 and $6.9 \%$, respectively, indicating that the immunoassay could distinguish between the carp sera with and without SVCV antibodies.

The results from the experiment to determine whether it was better to incubate carp serum and conjugate sequentially or simultaneously are shown in Fig. 2. At the 1:10, 1:20 and 1:80 dilutions of carp serum, sequential addition of carp serum and conjugate produced greater inhibition than simultaneous addition. Thereafter, carp sera and conjugate continued to be addod scquontially.

Sera from fish not exposed to SVCV showed less than $10 \%$ inhibition but for practical purposes, whilst the assay was under development, sera were considered negative if there was less than $20 \%$ inhibition. Nonspecific effects were not apparent when test sera were added to wells that did not contain SVCV antigen.

\section{Tests with sera from experimental fish}

Comparisons were made of neutralising antibody titres and percentage inhibition of sera from vaccinated carp surviving challenge with virulent SVCV. There were 2 different vaccination trials and the re-

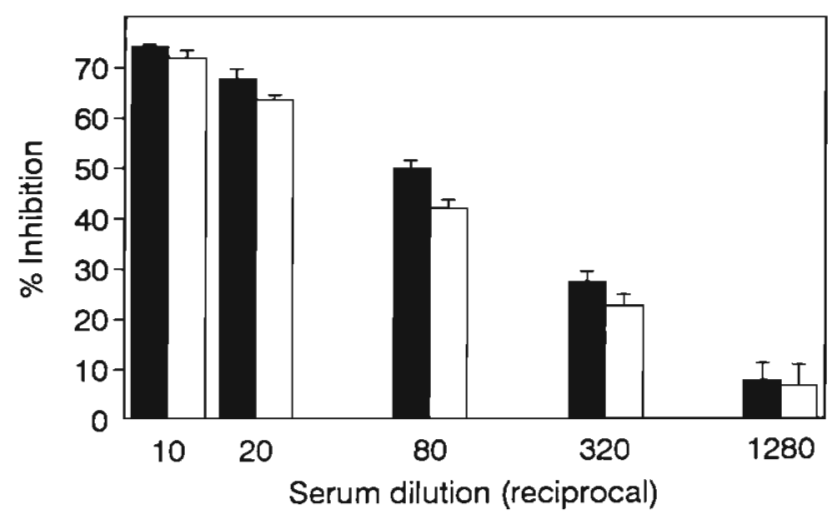

Fig. 2. Comparison of sequential ( $\square$ ) and simultaneous ( $\square$ ) addition of conjugate and competing carp serum in a competitive immunoassay for SVCV antibodies. Dilutions of carp serum were added to wells of microtitre plates containing capture antigen; following incubation and a wash, the conjugate was added (sequential addition). Alternatively, dilutions of carp serum and the conjugate were mixed together then added to wells of microtitre plates containing capture antigen (simultaneous addition). The concentrations of reactants were adjusted such that in both instances the final dilution of conjugate was 1:300 and the final dilutions of carp serum were $1: 10,1: 20,1: 80,1: 320$ and $1: 1280$. Mean (+SD) absorbance values are shown
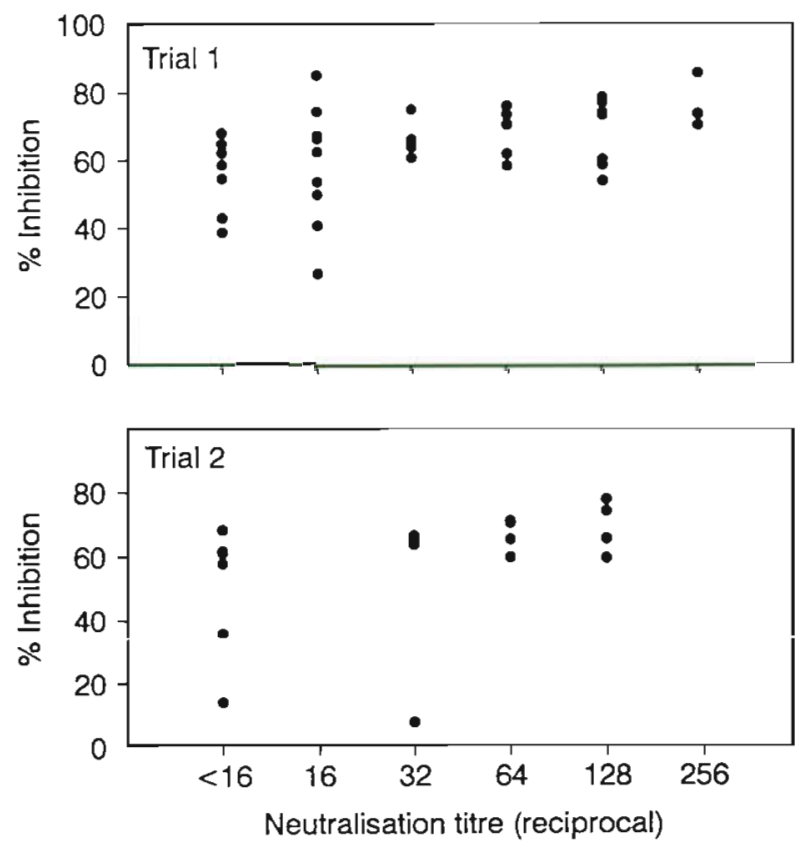

Fig. 3. Comparison of the competitive immunoassay and virus neutralisation test using carp sera from 2 vaccination/ challenge trials. Each datum point represents an individual carp serum tested by both methods

sults are shown in Fig. 3. There was little correlation between neutralising titre and percent inhibition (correlation coefficient 0.459 in Trial 1, 0.428 in Trial 2, 0.430 for combined data). It can be seen that there was inhibition with sera showing no neutralising antibodies. One fish serum had a neutralisation titre of $1: 32$, but was negative in the competitive assay $(7.6 \%$ inhibition); there was not enough of that serum to repeat the assay.

\section{Tests with field-collected sera}

Similar comparisons were done using sera from carp naturally exposed to SVCV. Four geographically distinct groups, designated A, B, C and D, of fieldcollected sera from fish in areas where SVCV was endemic were tested. Group A was positive and the other groups were negative by the neutralisation test. By the competitive immunoassay, $88.5 \%$ (23 out of 26 fish) of group A were positive compared with $34.6 \%$ (9 out of 26 fish) by the neutralisation test. Again, there was little correlation between the 2 methods (correlation coefficient 0.308 ). Antibody-positive fish were also identified in each of the other 3 groups by the competitive immunoassay: $11.4 \%$ (9 out of 79 fish) of Group B; $8.3 \%$ (6 out of 72 fish) of Group C; and $11.5 \%$ ( 6 out of 52 fish) of Group D. The serum from 1 fish showed $68 \%$ inhibition, but the percentage inhibition 


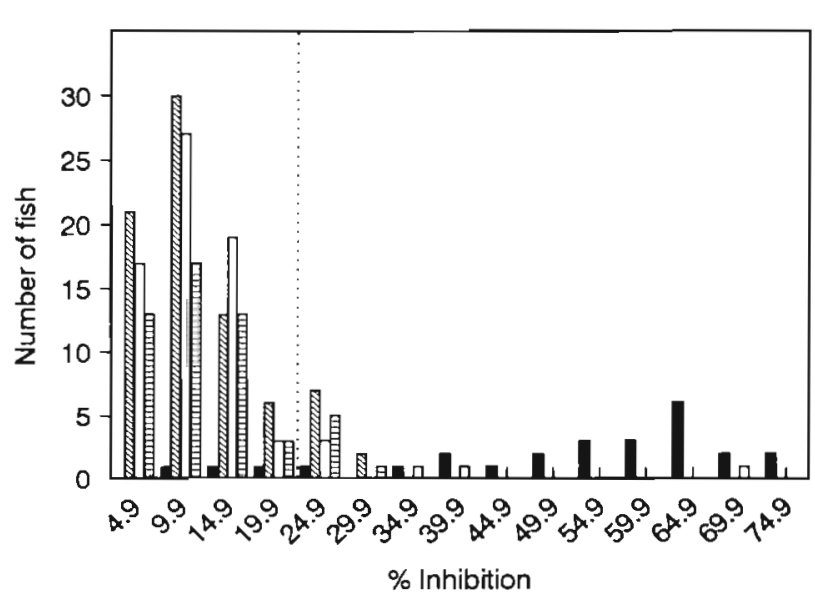

Fig. 4. Percentage inhibition frequencies of field-collected sera from carp in 4 regions where SVCV was endemic. Inhibition values to the right of the broken line are considered positive for SVCV antibodies. (U) Group A, (目) Group B,

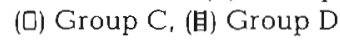

of the sera from the other fish was generally much lower. Fig. 4 shows the percentage inhibition frequencies of sera from the 4 groups.

\section{DISCUSSION}

A competitive immunoassay for detecting fish antibodies against SVCV was developed. Initially, the conditions for the assay were determined using rabbit immunoglobulins from an antiserum against SVCV in competition with an enzyme-immunoglobulin conjugate from the same antiserum. This was done to be certain that the test conditions employed were such that competition could occur. Having demonstrated that competition did occur with different concentrations of virus antigen and conjugate, a set of standard conditions needed to be determined for further tests. This was done on the following basis: the SVCV antigen needed to be at sufficient concentration such that, in the absence of competition, there would be a high $A_{405}$ reading at the end of the assay, but the concentration should not be so high that both test sera and conjugate could attach to binding sites on the antigen and not compete with each other; the conjugate needed to be at a concentration that was economical for routine use, and which would produce a high $A_{405}$ value in the absence of competition and a low $A_{405}$ value if competition occurred. The concentrations adopted on the basis of the initial tests proved to be satisfactory in subsequent tests with carp sera containing antibodies against SVCV. It was found to be better to add carp serum and conjugate sequentially rather than simultaneously (Fig. 2), although there was not a great differ- ence between the 2 procedures. The difference observed may be because the kinetics of the antibodyantigen reaction are more favourable to the conjugate (rabbit immunoglobulins). Sequential addition of carp serum and conjugate was used routinely, but simultaneous addition could be used if a reduction in the duration of the assay was needed.

Comparisons were initially made of the competitive immunoassay and neutralisation test using sera from vaccinated and virus-challenged fish (Fig. 3). Sera with and without neutralising antibodies were positive by the competitive immunoassay. One serum was positive for neutralising antibodies, but negative by the competitive immunoassay. Unfortunately, that result could not be checked as no more serum was available. The antibodies present in that serum may have degenerated during storage at $-20^{\circ} \mathrm{C}$, as has occurred with sera from a different source (data not shown), but such degeneration was not apparent with any other sera from Trials 1 and 2. Results from the competitive immunoassay showed that carp sera with no detectable neutralising antibodies were positive for other SVCV antibodies. The lack of correlation of the 2 methods is not unexpected as SVCV, being a rhabdovirus, comprises several different proteins, each of which can induce specific antibodies. Neutralising antibodies react with only 1 protein (the glycoprotein) of the virus, whereas in an immunoassay, antibodies against all the other virus proteins can react. For that reason, immunoassays are likely to be more sensitive than neutralisation tests. This has previously been discussed by Olesen et al. (1991) in relation to the rhabdovirus VHSV. However, a correlation between ELISA values and plaque neutralisation titres has been demonstrated for rainbow trout sera containing antibodies against another rhabdovirus, IHNV (Ristow et al. 1993). Olesen et al. (1991) showed that the levels of VHSV neutralising antibodies in rainbow trout sera declined more rapidly than non-neutralising antibodies. If that also occurs in carp sera in relation to SVCV antibodies, it would explain why non-neutralising sera produced high levels of inhibition.

The results from experimentally infected fish were mirrored by the results from field-collected sera. Neutralisation-positive sera produced high levels of inhibition, but sera of some fish from populations showing no neutralisation were also positive by the competitive immunoassay. In one instance, the inhibition was quite high $(68 \%)$, but in the majority of the remaining positive sera, inhibition was below $30 \%$. It may be that in all those sera, neutralising antibodies had declined to undetectable levels in the fish prior to their being bled, but a more likely explanation is that the competitive immunoassay is more sensitive than virus neutralisation, as discussed earlier. 
The initial reason for using a competitive rather than a direct immunoassay was so that SVCV antibodies in species other than carp could be tested for. All the developmental work utilised carp sera as a source of fish antibody against SVCV. Unfortunately, we had no fish sera known to contain SVCV antibodies other than those from common carp, and we were unable to initiate experimental infections because of a temporary lack of fish tank facilities. This aspect of the competitive assay will be addressed in future work.

Further validation of the competitive assay using a wider range of sera is required before it can replace the virus neutralisation test. Once that is done, the microtitre format of the assay, coupled with its relative speed (results obtained in $1 \mathrm{~d}$ ), will allow rapid largescalc scrconing of common carp stocks and potentially those of other species) to determine whether they have been exposed to SVCV. In turn, this will enable more effective and rapid management of the disease, particularly if it should occur in areas where it is not endemic.

\section{LITERATURE CITED}

Anonymous (1989). Spring viraemia of carp. MAFF Publications, Alnwick

Baudouy, A.-M. (1975). Virémie printanière de la carpe: premiers isolements du virus en France. Bull. Off. int. Epiz. 83: 717-722

Baudouy, A.-M., Danton, M., Merle, G. (1980). Virémie printanière de la carpe: étude expérimentale de l'infection évoluant à différentes températures. Annls Virol. (Inst. Pasteur) 131E: 479-488

Bucke, D., Finlay, J. (1979). Identification of spring viraemia in carp (Cyprinus carpio) in Great Britain. Vet. Rec. 104: 69-71

Chart, H., Pearson, T. W., Trust, I J. (1984). Detection of specific fish antibody using an inhibition enzyme-linked immunosorbent assay (inhibition ELISA). J. immunol. Methods 68: 19-24

Dixon, P. F. (1989). Immunoassays to detect fish antibodies directed against Renibacterium salmoninarum and infectious pancreatic necrosis virus: field studies. 4th Int. Conf. Eur. Ass. Fish Pathol, Abstract. University of Santiago de Compostela, Santiago de Compostela, p. 15

Dresenkamp, B. (1986). Frühjahrsvirämie der Karpfen. Mh. Vet-Med. 41.89-90

Fijan, N. (1988). Vaccination against spring viraemia of carp. In: Ellis, A. E. (ed.) Fish vaccination. Academic Press, New York, p. 204-215

Fijan, N., Matasin, Z., Jeney, Z., Olah, J., Zwillenberg, L. O. (1981). Isolation of Rhabdovirus carpio from sheatfish Silurus glanis fry. Proceedings of an international seminar. Fish, pathogens and environment in European polyculture. Szarvas, Hungary, p. 48-58

Fijan, N., Sulimanovic, D., Bearzotti, M., Muzinic, D., Zwillenberg, L. O., Chilmonczyk, S., Vautherot, J. F., Kinkelin, P. de (1983). Some properties of the Epithelioma papulosum cyprini (EPC) cell line from carp Cyprinus carpio. Annls Virol. (Inst. Pasteur) 134E: 207-220

Gravell, M., Malsberger, R. G. (1965). A permanent cell line from the fathead minnow (Pimephales promelas). Ann. N.Y. Acad. Sci. 126: 555-565
Groot, J. de, Dixon, P. F. (1989). The development of immunoassays to detect fish antibodies directed against Yersinia ruckeri, Renibacterium salmoninarum and infectious pancreatic necrosis virus. 4th Int. Conf. Eur. Ass. Fish Pathol., Abstract. University of Santiago de Compostela, Santiago de Compostela, p. 14

Hattenberger-Baudouy, A.-M., Danton, M., Merle, G. (1989a). Spring viraemia of carp (SVC): persistence of neutralising antibodies following experimental infection. 4 th Int. Conf Eur. Ass. Fish Pathol., Abstract. University of Santiago de Compostela, Santiago de Compostela, p. 63

Hattenberger-Baudouy, A.-M., Danton, M., Merle, G., Torchy, C., Kinkelin, P. de (1989b). Serological evidence of infectious hematopoietic necrosis in rainbow trout from a French outbreak of disease. J. aquat. Anim. Health 1: 126-134

Jørgensen, P. E. V. (1992). Recent advances in surveillance and control of viral haemorrhagic septicaemia (VHS) of trout. Proceedings of the OJI International Symposium on Salmonid Diseases. Hokkaido University Press, Sapporo, p. 60-71

Jørgensen, P. E. V., Olesen, N. J., Lorenzen, N., Winton, J. R., Ristow, S. S. (1991). Infectious hematopoietic necrosis (IHN) and viral hemorrhagic septicaemia (VHS): detection of trout antibodies to the causative viruses by means of plaque neutralization, immunofluorescence, and enzymelinked immunosorbent assay. J. aquat. Anim. Health 3: $100-108$

Kinkelin, P. de, Michel, C., Ghittino, P. (1985). Précis de pathologie des poissons. Institut National de la Recherche Agronomique - Office International des Epizooties, Paris

Kölbl, O. (1975). Neue Erkenntnisse über die Bauchwassersucht bei Karpfen. Österr. Fischerei 28: 69-72

Kretzschmar, C., Dresenkamp, B. (1987). Erste Versuche mit dem Festphasen-ELISA zum serologischen Nachweis der Frühjahrsvirämie der Karpfen im Vergleich zum Serumneutralisationstest. Mh. Veterinární Medicína 42: 64-67

Mulcahy, D., Jenes, C. K., Pascho, R. (1984). Appearance and quantification of infectious hematopoietic necrosis virus in female sockeye salmon (Oncorhynchus nerka) during their spawning migration. Arch. Virol. 80: 171-181

Olesen, N. J., Lorenzen, N., Jargensen, P. E. V. (1991). Detection of rainbow trout antibody to Egtved virus by enzymelinked immunosorbent assay (ELISA), immunofluorescence $(\mathrm{IF})$, and plaque neutralization tests ( $50 \% \mathrm{PNT})$. Dis. aquat. Org. 10: 31-38

Ristow, S. R., Avila, J de, LaPatra, S. E., Lauda, K. (1993) Detection and characterization of rainbow trout antibody against infectious hematopoietic necrosis virus. Dis. aquat. Org. 15: 109-114

Rodák, L., Pospísil, Z., Tománek, T., Vesely, T., Hampl, J (1986). Enzymoimunologická (ELISA) diagnostika jarní virémie kapru. Vet. Med. 31. 505-512

Roudikov, N. I. (1980). La virose printanière des poissons en U.R.S.S. Bull. Off. int. Epiz. 92: 1069-1077

Shchelkunov, I. S., Shchelkunova, T I. (1989). Rhabdovirus carpio in herbivorous fishes: isolation, pathology, and comparative susceptibility of fishes. In: Ahne, W., Kurstak, E. (eds.) Viruses of lower vertebrates. Springer, Berlin, p. $333-348$

Stoker, M., McPherson, I. (1961). Studies on transformation of hamster cells by polyoma virus in vitro. Virology 14 : $359-370$

Way, K. (1991). Rapid detection of SVC virus antigen in infected cell cultures and clinically diseased carp by the enzyme-linked immunosorbent assay (ELISA). J. appl. Ichthyol. 7: 95-107

Manuscript first received: December 9, 1993

Revised version accepted: May 19, 1994 